\title{
Characterization and preliminary risk assessment of road dust collected in Venice airport (Italy)
}

\author{
Gabrio Valotto $^{\mathrm{a}, *}$, Daniele Zannoni ${ }^{\mathrm{a}}$, Giancarlo Rampazzo ${ }^{\mathrm{a}}$, Flavia Visin ${ }^{\mathrm{a}}$, Gianni Formenton ${ }^{\mathrm{b}}$, \\ Alessandra Gasparello ${ }^{\mathrm{b}}$ \\ a Department of Environmental Sciences, Informatics and Statistics, Università Ca' Foscari Venezia, I-30123 Venezia, Italy \\ b Dipartimento Provinciale di Venezia, Agenzia Regionale per la Prevenzione e Protezione Ambientale del Veneto (ARPAV), I-30174 Mestre, Italy
}

\section{A R T I C L E I N F O}

\section{Keywords:}

Road dust

Airport

Airside

Landside

Risk assessment

\begin{abstract}
A B S T R A C T
Road dust is a non-exhaust source that can significantly contribute to atmospheric particulate by resuspension. Beside the issue of the overcoming of guidelines limits for the air quality, the characterization of this matrix is of crucially high interest for the inherent toxicity of resuspended particles, that can act as carriers of heavy metals and toxic-carcinogenic components.

In this paper, road dust collected in the Venice international airport is characterized with a multi-technique approach in order to identify the main pollutant sources and to highlight the differences between airside/ landside places. The most polluted sites are identified and a preliminary risk assessment is performed taking into account ingestion, dermal intake and inhalation of fugitive particulate pathways. Specifically, the main sources are related to construction activities, anti-icing safety procedures, and brake, tire and road wear; streets are the most polluted landside places; $\mathrm{PAHs}, \mathrm{Na}, \mathrm{Al}, \mathrm{Cu}, \mathrm{Zn}, \mathrm{Ag}, \mathrm{Cd}$ are more concentrated in airside area; as regards the risk assessment $\mathrm{As}, \mathrm{BaP}, \mathrm{Cr}, \mathrm{Sb}, \mathrm{BaA}$, and $\mathrm{BbF}$ are the most critical pollutants.

Considering the high number of people passing or working in this airport and the ongoing works related to its enlargement which promotes the emission and the resuspension of fugitive dusts, this research addresses a fundamental step for the protection of potential receptors.
\end{abstract}

\section{Introduction}

Road traffic is an important source of atmospheric particulate matter in urban and industrialized areas (e.g., Thorpe and Harrison, 2008; Wik and Dave, 2009; Franco et al., 2013; Kumar et al., 2013; Pant and Harrison, 2013; Amato et al., 2014; Grigoratos and Martini, 2015; Suvarapu and Baek, 2016; Timmers and Achten, 2016). It includes exhaust and non-exhaust emissions. The former are related to the fuel combustion, the others are due to the wear of brake systems (pads and discs), tires, road surface abrasion and re-suspension of road dust (RD) finer particles. The latter matrix is composed by natural and anthropogenic materials that accumulate on the road surface mainly close to the pavements (Pant and Harrison, 2013, and references therein) and that can be resuspended by wind and traffic flow.

In the last decade the relative contribution to fine atmospheric particulates of non-exhaust sources has become more and more relevant because most of the recent policy actions and technological upgrades in the automotive field were just focused on the reduction of exhaust emissions (Bukowiecki et al., 2009; Rexeis and Hausberger, 2009; van der Denier Gon et al., 2012; Timmers and Achten, 2016). In this regard, it is worth to highlight that electric vehicles may not reduce levels of atmospheric particulate as much as expected, because of their relatively high weight (on average $24 \%$ heavier than equivalent internal combustion engine) which increase the emissions of non-exhaust sources such as the brake, tire and asphalt wear (Timmers and Achten, 2016).

As mentioned above, RD is a non-exhaust source by resuspension of finer particles which chemical composition, size distribution and percentage contribution to the atmospheric particulate is site specific (Bukowiecki et al., 2009; EMEP/EEA, 2016; Grigoratos and Martini, 2014; Pant and Harrison, 2013; Valotto et al., 2015). In this regard, since RD is also composed of particles originated from other non-exhaust sources, the discrimination between particles directly emitted from abrasion process and those related to the re-suspension is an open issue (Pant and Harrison, 2013).

The technical guidance of European Environment Agency (EMEP/ EEA, 2016) for the evaluation of non-exhaust contributions includes the wear of tires, brakes and road surfaces categories, but ignores the resuspension process which dominates in some European areas

\footnotetext{
* Corresponding author at: Ca' Foscari University of Venice, Via delle Industrie n. 21/8 c/o INCA-VEGAPARK, 30175 Marghera, VE, Italy.

E-mail address: valotto@unive.it (G. Valotto).
} 
(Weinbruch et al., 2014; Amato et al., 2014 and references therein). Otherwise, more complex models such as TNO URBIS (URBIS, 2016; Amato et al., 2016) and NORTRIP (Denby et al., 2013a, b) take into account also the road dust resuspension to predict the whole non-exhaust particle emissions.

Although the inherent toxicity of RD particles that can act as carriers of heavy metals and carcinogenic components it is well assessed (e.g.: Dong and Lee, 2009; Shi et al., 2011; Pant and Harrison, 2013), up to now does not exist a dedicated model to perform the risk assessment for this matrix. Indeed, most of the researches focused on this topic use the approaches provided by US Environmental Protection Agency which allow to estimate the soil contamination of superfund sites (USEPA, 1996, 2002), to evaluate the exposure pathways of RD matrix and the respective potential health risks (e.g.: Li et al., 2015; Chen et al., 2016; Wan et al., 2016; Yekeen et al., 2016).

The inorganic composition of RD in the Venice mainland has been previously studied with a wide (Zannoni et al., 2016) and a very localized (Valotto et al., 2015) sampling campaigns which allowed to identify the main sources of particles. However, the characterization of organic compound and the related risk assessment are still lacking in this area.

In this work, risk assessment related to the exposure of inorganic and organic components of RD collected in the Venice international airport area was performed taking into account the following intake pathway: ingestion, dermal intake and inhalation of fugitive particles. The sampling site, whose air pollution was deeply investigated (Valotto et al., 2014; Valotto and Varin, 2016), is a sensitive area due to the high number of workers and tourists which attend it. Indeed, it was the fourth busiest Italian airport in 2015 in terms of number of flights $(\approx 82,000)$ and the fifth in terms of number of passengers $(\approx 8,800,000)$ (Assaeroporti, 2016). Moreover, the existing maintenance and extension builds (Marcopolodomani, 2016) promote the emission and the resuspension of fugitive dusts, placing this research a fundamental step for the protection of potential receptors. To the best of the authors knowledge, the risk related to $\mathrm{RD}$ exposure has never been assessed in any airport areas and the PAHs bound to RD particles has never been characterized in Italy.

Samples were collected in landside and airside areas of the airport, and characterized by a multi-technique approach to determine the different composition depending on sampling sites peculiarities and to identify the main pollutant sources of particles. Specifically, particle size distribution as well as elemental and molecular (polycyclic aromatic hydrocarbon - PAHs) composition of sub-samples most subjected to re-suspension process (characterized by particle size lower than $37 \mu \mathrm{m}$ and between 37 and $63 \mu \mathrm{m}$ ) were probed by laser diffraction analysis, Total Carbon (TC) analysis, High Performance Liquid Chromatography (HPLC), Inductively Coupled Plasma Optical Emission Spectroscopy (ICP-OES), and Inductively Coupled Plasma Mass Spectrometry (ICP-MS). Data were processed with Cluster Analysis (CA) and Principal Component Analysis (PCA) statistical approaches.

\section{Materials and methods}

\subsection{Sampling sites}

The Venice international airport is located near the Venice Lagoon in the North-Eastern Italy between the Po Valley, and the Adriatic Sea. Twenty RD samples were collected in the airport area on 27 May 2016 after two days without rainfall events. The former nine days (16th-24th May 2016) were characterized by $10 \mathrm{~mm}$ of total rain. 19 samples (\# 1-19) were collected in landside using small brooms and dustpans (one couple for each sample which is of about $300 \mathrm{~g}$ ) inside the parking lots, close to the sidewalks of the main streets and near the roundabouts neighboring to the airport as indicated in Fig. 1 (for further details see Sampling Sites. kmz file of Supplementary Materials). One sample (\# 20) was collected in the storage area of RD gathered by sweepers cleaning the taxiways and airport apron (airport area where aircraft are parked, unloaded or loaded, refueled, or boarded), which is deposited temporarily until it was transported to treatment and disposal facilities. Moreover, about $1000 \mathrm{~g}$ of soil were collected between 3 and $15 \mathrm{~cm}$ depth at the nearby park "Forte Bazzera" (\#21), in order to investigate the enrichment factors (EFs) and Pollution Load Index (PLI) of RD samples.

Soil and RD samples were initially dry sieved using a series of decreasing mesh ASTM standard sieves to obtain sub-samples characterized by grain sizes $<37 \mu \mathrm{m}$ (referred to in the text as "fine fraction"). Subsequently, sub-samples characterized by grain sizes $>37 \mu \mathrm{m}$ were wet sieved with de-ionized water to obtain powders with particles size between 37 and $63 \mu \mathrm{m}$ (referred to in the text as "coarse fraction"). After sieving all powder samples were conditioned in an oven at $50{ }^{\circ} \mathrm{C}$ for about seven days and subsequently stored in PTFE sample holders.

It is worth to note that samples 1 and 9 contain a low quantity of both fractions $(<37 \mu \mathrm{m}$ and $37-63 \mu \mathrm{m})$, which did not allow to accurately characterize these sub-samples with all the techniques described below.

\subsection{Particle sizes}

About 0.3 and $0.6 \mathrm{~g}$ of fine and coarse dust sub-samples, respectively, were dispersed in $700 \mathrm{ml}$ of diluted Tween $^{\circledR} 20(\mathrm{vol} / \mathrm{vol}=1$ / 100,000), and investigated with a Mastersizer $3000^{\circledR}$ (Malvern, UK) laser diffractometer to characterize the particle size distributions. During measurements stirrer speed and ultrasonics were set to $2200 \mathrm{rpm}$ and $50 \%$ to prevent the sedimentation and the aggregation of suspended particles, respectively. Ten measurements were performed for each sample using the Fraunhofer approximation and general purpose analysis model, obtaining very precise results. Subsequently representative average volume distribution curves were calculated processing only measurements with weighted residual lower than $1 \%$ (at least 9 measurements for each sample). Note that sub-samples $1<37$, $1_{37-63}$ and $9<37$ were not probed.

\section{3. $T C$}

About $9 \mathrm{mg}$ of each sub-sample were characterized by Shimadzu (Japan) TOC - V CPH equipped with a solid sample combustor SSM$5000 \mathrm{~A}$ module, by catalyzed oxidative conversion to $\mathrm{CO}_{2}$ at $900{ }^{\circ} \mathrm{C}$ and subsequent detection with a NDIR detector. The instrument calibration was performed with $\mathrm{D}(+)$ glucose anhydrous (AnalytiCals Carlo Erba). For further details about the quality assurance and quality control (QA) $\mathrm{QC})$, refer to supplementary materials. Note that sub-sample $1<37$ was not probed.

\section{4. $P A H s$}

Eight PAHs, including fluoranthene (Fluo), pyrene (Py), benzo(a) anthracene $(\mathrm{BaA})$, benzo $(b)$ fluoranthene $(\mathrm{BbF})$, benzo $(k)$ fluoranthene $(\mathrm{BkF})$, benzo( $a$ )pyrene (BaP), benzo $(g, h, i)$ perylene (BghiP), indeno $(1,2,3-c, d)$ pyrene (IP) were identified and quantified after solvent extraction.

A 2695 series Alliance HPLC (Waters, USA) with quaternary pump, auto-sampler, microdegasser, column thermostat was interfaced with a 2475 multi $\lambda$ fluorescence detector. HPLC was set as following: reversed phase chromatographic column (LC-PAH, $15 \mathrm{~cm} \times 3 \mathrm{~mm}, 5 \mu \mathrm{m}$, Supelco, USA) at a temperature of $25^{\circ} \mathrm{C}$, injection volume $20 \mu \mathrm{L}$, mobile phase system consisting of a ramp mixture of ultrapure $\mathrm{H}_{2} \mathrm{O}$ and acetonitrile at a flow rate of $0.45 \mathrm{~mL} \mathrm{~min}^{-1}$ as reported in Table $\mathrm{S} 1$ of Supplementary materials. The instrument was properly calibrated with five diluted aliquots of a standard containing the EPA's 16 PAHs (Ultra Scientific, USA).

About $20 \mathrm{mg}$ of each sub-sample was weighted with an analytical balance of nominal sensitivity $0.01 \mathrm{mg}$ and ultrasonically extracted for 


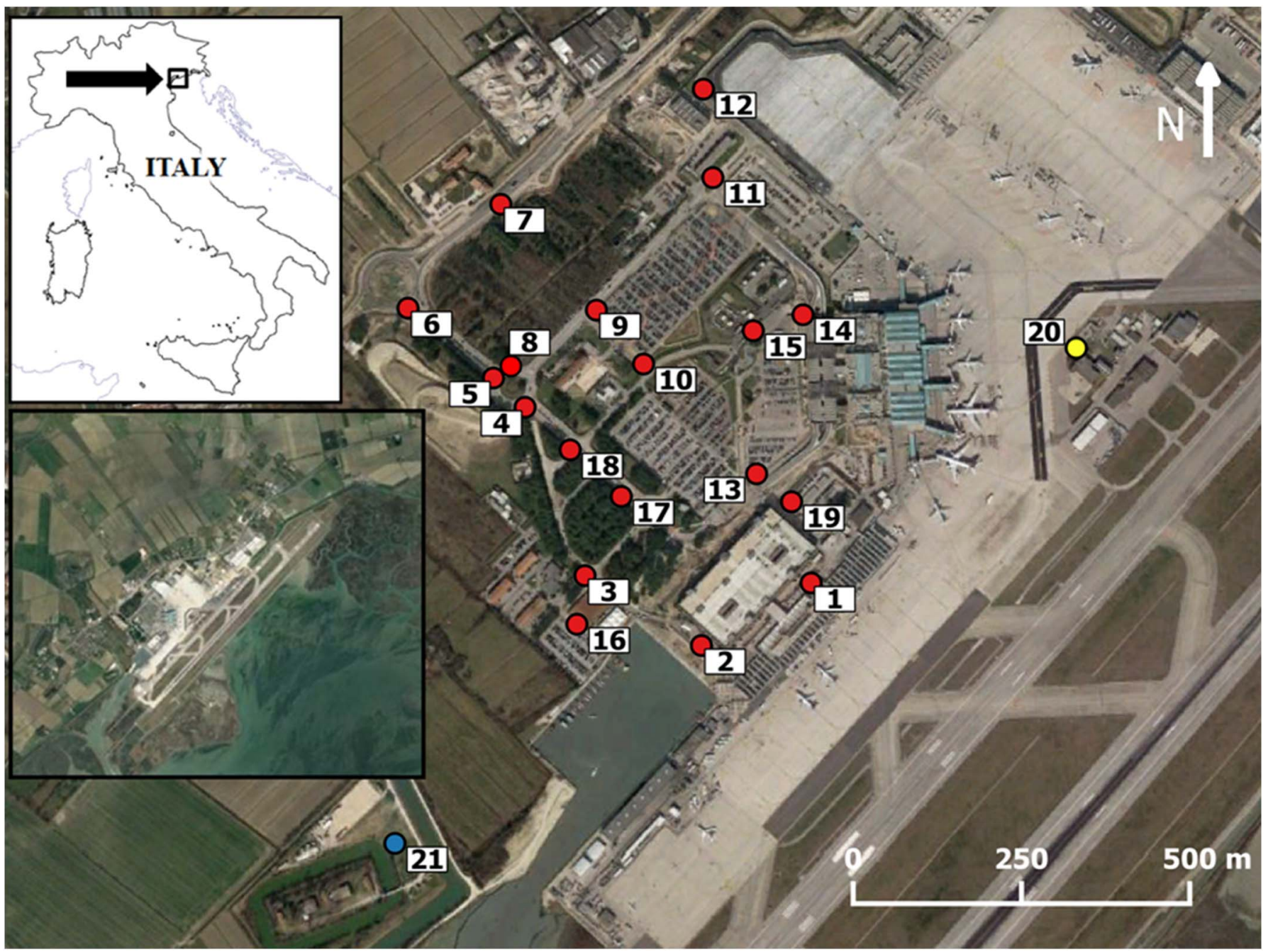

Fig. 1. Road dust and soil sampling sites.

$25 \mathrm{~min}$ in $5 \mathrm{ml}$ of acetonitrile (HPLC grade, 99.9\%, Sigma-Aldrich, USA). The extracts were subsequently filtered on PTFE syringe filters (porosity $0.22 \mu \mathrm{m}$ ). Further details about QA/QC are in supplementary materials. Note that sub-samples $1<37$ and $9<37$ were not probed.

\subsection{ICP-OES, ICP-MS}

About $70 \mathrm{mg}$ of each sub-sample were weighted with an analytical balance of nominal sensitivity $0.01 \mathrm{mg}$ and digested by microwave digestion system (Ethos 1600, Microwave Labstation Milestone - $5 \mathrm{~min}$ $250 \mathrm{~W}, 5 \mathrm{~min} 400 \mathrm{~W}, 5 \mathrm{~min} 600 \mathrm{~W}, 60 \mathrm{~min} 0 \mathrm{~W}, 5 \mathrm{~min} 250 \mathrm{~W}, 5 \mathrm{~min}$ $400 \mathrm{~W}, 5 \mathrm{~min} 600 \mathrm{~W}, 120 \mathrm{~min} 0 \mathrm{~W}$ ) with $6 \mathrm{ml}$ of $\mathrm{HNO}_{3}, 2 \mathrm{ml}$ of $\mathrm{H}_{2} \mathrm{O}_{2}$ and $1 \mathrm{ml}$ of $\mathrm{HF}$ of analytical grade. After cooling, HF was buffered with $1 \mathrm{ml}$ of $\mathrm{H}_{3} \mathrm{BO}_{3}$ saturated solution and the resulting clear solution was then filtered on PTFE syringe filters (porosity $0.45 \mu \mathrm{m}$ ) and diluted to $25 \mathrm{ml}$ with Milli-Q ${ }^{\circledR}$ water. All digested samples were then stored in Teflon bottles. The digested and properly diluted samples were analyzed with ICP-OES (Perkin Elmer 5300DV) and ICP-MS (Perkin Elmer NexION 350X). Na, Mg, Al, S, K, Ca, Ti, Cr, Mn, Fe, Ni, Cu, Zn, Ba, Pb were analyzed with ICP-OES; Li, Sc, V, Co, As, Mo, Ag, Cd, Sb, U were analyzed with ICP-MS in Kinetic Energy Discrimination (KED) mode (He gas). Commercially available $1000 \mathrm{mgl}^{-1}$ standard solutions (Fluka TraceCERT ${ }^{\circledast}$ ) of the analyzed elements were used to calibrate ICP-OES. Multi-Element Calibration Standard $310 \mathrm{mg} \mathrm{l}^{-1}$ solution (Perkin Elmer) was used to calibrate ICP-MS. Re $\left(5 \mu \mathrm{g}^{-1}\right)$ was used as internal standard for ICP-MS analysis. Diluted working solutions were daily prepared by serial dilutions of the stock solutions (1:20 to $1: 5$ and 1:2, for ICP-OES and ICP-MS, respectively). Three blank solutions not containing dusts were carried through the same procedure to correct the elemental contributions of reagents used for samples preparation. Further details about QA/QC are in supplementary materials. Note that sub-samples $1_{<37}$ and $1_{37-63}$ were not probed.

\subsection{Statistical analysis}

EF, PLI, CA and PCA were carried out in order to identify relations between the compositions and the particle size distributions of $\mathrm{RD}$ samples and to recognize the most polluted sites of the monitored area. Analysis were performed using the commercial statistics software package Statistica 8.0.

EF and PLI were calculated as defined in Eq. (1) (Fujiwara et al., 2011a) and Eq. (2) (Tomlinson et al., 1980; Yekeen et al., 2016), respectively:

$$
\mathrm{EF}=\frac{\left(\frac{\mathrm{X}_{\mathrm{i}}}{\mathrm{TC}}\right)_{\mathrm{RD}}}{\left(\frac{\mathrm{X}}{\mathrm{TC}}\right)_{\text {soil }}}
$$

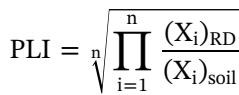

where $\mathrm{n}$ is the number of probed pollutants, $\mathrm{X}_{\mathrm{i}}$ and TC are the concentration values of the pollutant of interest and of normalization in the 
matrices indicated by the subscripts, respectively. We choose the total carbon as normalization because: i) all powder samples show concentrations significantly higher than the respective LOQ; ii) it is characterized by the lowest values of percentage standard deviation of RD samples ( $14 \%$ for $\mathrm{RD}<37$ and $15 \%$ for $\left.\mathrm{RD}_{37-63}\right)$; iii) it includes inorganic and organic carbon and then it is suitable to calculate the EF of both elements and PAHs; iv) soil sub-samples are characterized by comparable concentrations of TC, which are significantly lower than those of RD samples (4\% vs 7-12\%). For concentrations lower than the respective limit of quantification (LOQ), we use the LOQ/2 value to calculate the respective EF and PLI.

Moreover, the spatial variation of PLI in the monitored area was investigated with the Inverse Distance Weighted (IDW) method. With this, the continuous spatial distribution of a variable can be obtained interpolating data from discrete points. In IDW the local contribution of a measured point diminishes with distance and each point of the resulting map is calculated as a weighted average of nearby points where the weight is proportional to distance ${ }^{-1}$. Interpolation of PLI data for both fractions was computed with QGIS software, using a distance coefficient of 5. RD samples \#1, \#20, \#21 were removed from the interpolation dataset because: only the coarse fraction of \#1 was available; \#20 is not representative of a point but of the whole cleaned surface in the airside area; \#21 is the soil control sample which was collected outside the airport area.

CA is a statistical classification technique allowing to organize observed data into meaningful structures, so that objects belonging to the same group (named cluster) are more similar to each other than those in other clusters (Kaufman and Rousseeuw, 2009). CA was applied to raw data of volume particle size distributions (no pre-normalization has been performed) to identify the groups of RD samples resolved in fine and coarse fractions.

PCA is a statistical exploratory technique that allows for simplifying the interpretation of acquired data by reducing the dimensionality of a dataset. The size reduction is achieved with linear combinations of the original variables. This operation gives a set of new non-correlated variables named principal components (PCs), which are equal in number to the previous ones but only a reduced number of them are necessary to describe the main characteristics of the initial dataset. The amount of information of each PC is usually named explained variance and is complementary to that of the other PCs. PCA is based on the investigation of loading and score plots; the former show the contribution of the original variables in each PC, the latter are the representation of each object in the space of the selected PCs (Jolliffe, 2002). In order to reduce the number of variables related to the particle size distributions, the respective dataset was compacted by adding the percentage volumes of particles belonging to the following size groups: < 1, 1-5, 5-10, 10-20, 20-30, 30-40, 40-50, 50-60, 60-70, $70-80,80-90,90-100,>100 \mu \mathrm{m}$. Accordingly, PCA was applied to the dataset composed of 37 samples (fine and coarse fractions together) and 46 variables (13 size groups, 26 elements, 7 PAHs) to identifying patterns among concentrations and particle size classes. RD sub-samples $1<37,1_{37-63}, 9<37$ were not considered due to the absence of several information. Moreover, Ind 123cdP was excluded from the dataset due to the high number of concentrations lower than the respective LOQ value. As in the cases of EF and PLI, for concentrations lower than the respective LOQ, we used the LOQ/2 value. Prior to the evaluation of the loading and score plots, to make comparable the intensity ranges of all variables, the values of each single variable were normalized by imposing the mean and standard deviation values equal to 0 and 1 , respectively.

\subsection{Risk assessment}

$\mathrm{RD}$ concentrations were compared with the soil screening levels (SSLs) provided by US Environmental Protection Agency (USEPA, 1996, 2002) in order to perform a preliminary risk assessment related to the interaction of this matrix with the potential receptors. Several works utilized the more complex site specific modeling approach to evaluate the exposure pathways of RD matrix and the respective potential health risks (e.g.: Li et al., 2015; Chen et al., 2016; Wan et al., 2016; Yekeen et al., 2016). Instead, due to the different characteristics of RD and soil matrices, and the peculiarities of the monitored area, we preferred to apply the generic SSLs which are more stringent because they are calculated by EPA by using conservative assumptions about site conditions. Specifically, we chose this precautionary approach because most of the RD samples were collected near the potential receptors, namely close to the sidewalks along the neighboring airport streets crossed by passengers and workers where $\mathrm{RD}$ is resuspended by traffic flow (in addition to the wind action) to a great extent than the soil source, located farthest from the sampling sites at issue and characterized by a significant vegetative cover (for further details refer to Sampling Site. $\mathrm{kmz}$ file). In order to take into account the different permanence of all potential receptors (workers, regular and occasional passengers), $\mathrm{RD}<37$ and $\mathrm{RD}_{37-63}$ concentrations (averages and highest values) were compared with the generic SSLs for residential and commercial/industrial (outdoor and indoor workers) scenarios, and ingestion + dermal intake and inhalation of fugitive particles pathways. Results are reported as ratios between the RD concentrations and the SSLs values.

\section{Results}

\subsection{Particle sizes}

The left panels of Fig. 2 show the hierarchical tree-plots of fine and coarse RD samples drawn with Ward's agglomeration method and Euclidean distance measure. While, the right ones depict the average particle size distribution curves of clusters identified at Dlink/ Dmax $=50 \%$. Results show that at this linkage distance, both subsamples can be grouped in three macro groups without clear correspondence between fine and coarse fractions. The seeming incongruence between the particle size distributions and the ASTM standard sieves used to create the sub-samples are related to the presence of: i) elongated particles crossing the mesh of sieves which are revealed larger than their lower diameter, ii) clusters of fine particles which are not disaggregated during the wet sifting.

On average, all sub-samples show quite similar particle size distributions with mode at about 24.0 and $56.6 \mu \mathrm{m}$ for fine and coarse fractions, respectively. The mode of each cluster and the respective average percentage volume of particles lower than $1 \mu \mathrm{m}, 2.5 \mu \mathrm{m}$ and $10 \mu \mathrm{m}$ are reported in Table 1 , confirming that this matrix could be an important source of atmospheric particulate by re-suspension.

Sub-samples belonging to $\mathrm{B}<37$ and $\mathrm{C}<37$ are characterized by a higher amount of particles lower than $10 \mu \mathrm{m}$ and higher than $30 \mu \mathrm{m}$, respectively. While, the particle size distribution of $\mathrm{A}_{<37}$ exhibit intermediate characteristics between the two abovementioned clusters. As regards the coarse fraction, $F_{37-63}$ is richer in particles lower than $40 \mu \mathrm{m}$ compared to the quite similar clusters $D_{37-63}$ and $E_{37-63}$.

\subsection{Inorganic and organic concentrations}

Table 2 shows some statistics related to the concentrations, EF and PLI values of RD sub-samples. For the calculation of the average concentrations and the respective standard deviations, values lower than LOQ where replaced with LOQ/2. Moreover, the concentrations of two sampling campaign carried out in two hot spot traffic areas of the Venice mainland (road dust samples, Valotto et al., 2015; atmospheric particulate samples, Valotto et al., 2017a) are also reported. While, Fig. 3 shows the spatial variation of PLI in the monitored area.

On average, fine fractions are characterized by the higher concentrations, especially for PAHs, $\mathrm{Li}, \mathrm{Cr}, \mathrm{As}, \mathrm{Ag}, \mathrm{Cd}, \mathrm{Sb}$ and U. Only sodium is significantly more concentrated in the coarse fractions. For 

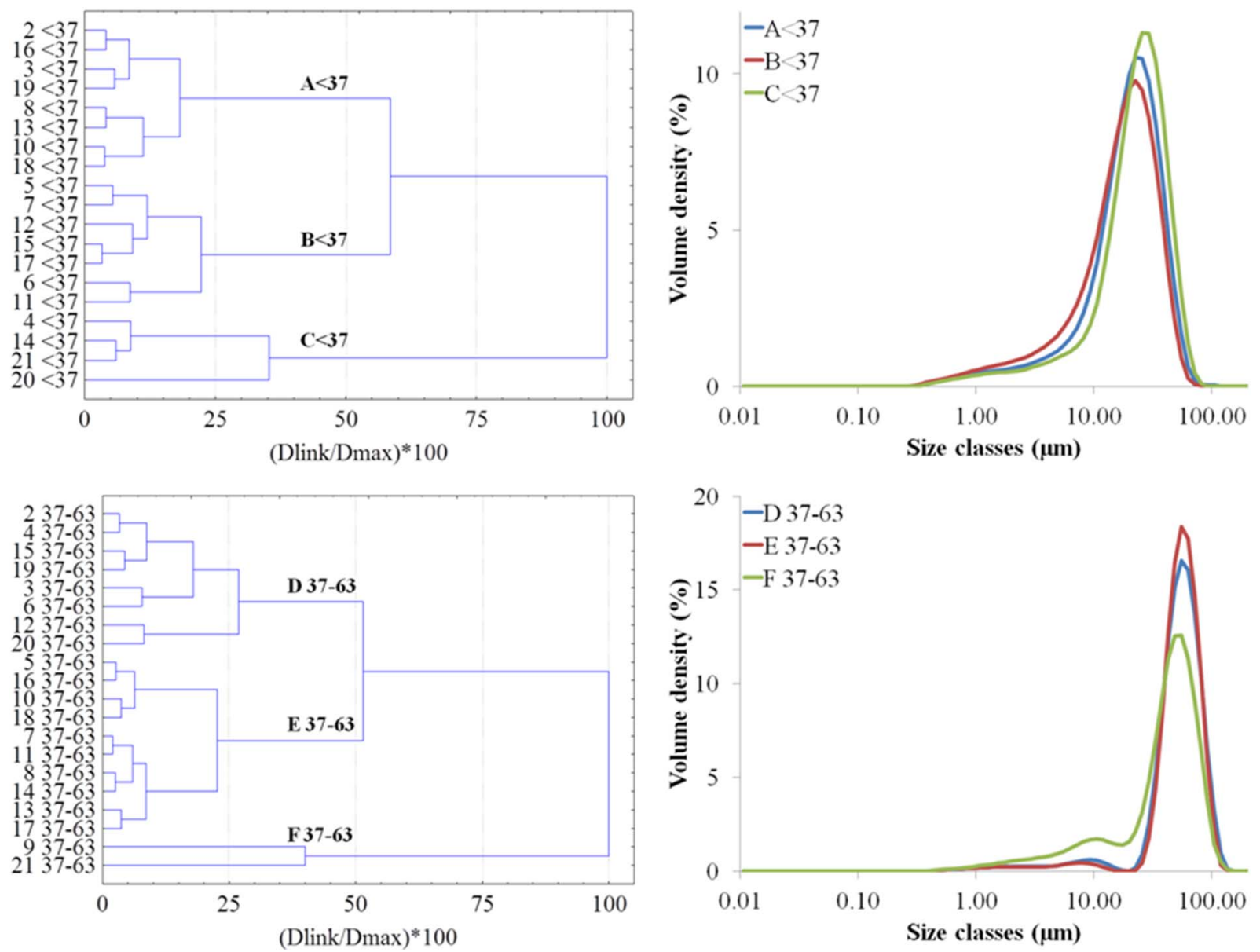

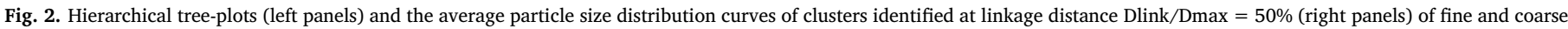
sub-samples.

Table 1

Mode values and average percentage volume of particles lower than $1 \mu \mathrm{m}, 2.5 \mu \mathrm{m}$ and $10 \mu \mathrm{m}$ of each cluster.

\begin{tabular}{lllll}
\hline Cluster & Mode $(\mu \mathrm{m})$ & $<1 \mu \mathrm{m}$ (volume \%) & $2.5 \mu \mathrm{m}$ (volume \%) & $10 \mu \mathrm{m}$ (volume \%) \\
\hline $\mathrm{A}_{<37}$ & 23.8 & 1.8 & 5.0 & 18.0 \\
$\mathrm{~B}_{<37}$ & 22.4 & 2.1 & 6.3 & 24.2 \\
$\mathrm{C}_{<37}$ & 27.2 & 1.5 & 4.1 & 13.6 \\
$\mathrm{D}_{37-63}$ & 57.1 & 0.5 & 1.9 & 5.3 \\
$\mathrm{E}_{37-63}$ & 57.1 & 0.6 & 1.9 & 4.8 \\
$\mathrm{~F}_{37-63}$ & 52.3 & 0.8 & 3.5 & 13.0 \\
\hline
\end{tabular}

both the fractions, PAHs, Mg, S, Ca, Cu, Zn, Mo, Sb, and Pb show the higher EF values. Both fractions of RD sample collected in airside (\#20) show the respective higher values of PLI because, on average, they are characterized by higher concentrations than those of RD collected in landside (\#1, ..., \#19), especially for PAHs, Na, Al, Cu, Zn, Ag, Cd. On average, $\mathrm{RD}<37$ samples collected in the airport area show concentrations lower than the road dust with particle size lower than $37 \mu \mathrm{m}$ $(\mathrm{TRD}<37)$ and $\mathrm{PM}_{1}$ collected in two different traffic sites close to the airport at issue. Specifically, the highest differences were detected for $\mathrm{PAHs}$ bound to $\mathrm{PM}_{1}$ and for $\mathrm{Cr}, \mathrm{Cu}, \mathrm{Mo}, \mathrm{Pb}$ of $\mathrm{TRD}<37$. For further details about concentration ratios above discussed and the algorithms used to evaluate if values are significantly different, refer to Figs. S1-S5 and Table S3 of supplementary materials, respectively.

As regards the spatial distributions of PLI shown in Fig. 3, streets are characterized by higher values, while the low PLI areas highlight the airport parks.

\subsection{Statistical}

The loadings of significant PCs identified with Krzanowski crossvalidation method are reported in Table 3. The respective explained and cumulative variance are also included as percentage values; overall the cumulative explained variance of five PCs is about $85 \%$. The higher coefficients (as absolute value) of each PCs are in bold. Loading and score plots are reported in Figs. S6-S10 of Supplementary materials. Scatter score-plots of selected PCs are also reported in Fig. S11. In order to improve the readability of this work, the loadings and scores characteristics will be introduced and discussed in Section 4 .

\subsection{Risk assessment}

Fig. 4 shows the ratios between the $\mathrm{RD}<37$ concentrations and the SSLs for residential and commercial/industrial (indoor - outdoor workers) scenarios, resolved between ingestion + dermal intake and inhalation of fugitive particulates pathways. The histogram bars and whiskers are related to the average and the highest concentrations, respectively. The ratio equal to 1 is highlighted by the red horizontal line. The histogram of $\mathrm{RD}_{37-63}$ is reported in Fig. $\mathrm{S} 12$ of supplementary materials.

Results shows that two histograms are quite similar, and that As is the more critical pollutant. Indeed, the average concentrations of both fractions are significantly higher than the respective SSLs for all scenarios (residential and commercial/industrial worker) related to the ingestion + dermal intake. Also the average concentration of $\mathrm{BaP}$ of fine fraction is higher than the respective SSLs for the ingestion + dermal intake of residential scenario. Moreover, the highest 
Table 2

Concentrations and statistics related to RD sub-samples.

\begin{tabular}{|c|c|c|c|c|c|c|c|c|c|c|c|}
\hline & $\begin{array}{l}\overline{R D<37} \\
\mathrm{SD}<37 \\
\mathrm{MAX}_{<37}\end{array}$ & $\begin{array}{l}\overline{R D}_{37-63} \\
\mathrm{SD}_{37-63} \\
\mathrm{MAX}_{37-63}\end{array}$ & $\mathrm{HC}$ & $\frac{\# 20<37 ?}{\text { landside }<37}$ & $\frac{\# 20_{37-63} ?}{\text { landside }_{37-63}}$ & $\overline{E F<37}$ & $\begin{array}{l}\text { MAX } \\
\mathrm{EF}<37\end{array}$ & $\overline{E F_{37-63}}$ & $\begin{array}{l}\mathrm{MAX} \\
\mathrm{EF}_{37-63}\end{array}$ & $\begin{array}{l}\overline{\text { PreC }} \\
\text { SDPreC } \\
\text { Previous } \\
\text { Campaign }\end{array}$ & $\overline{R D_{<37}} ? \overline{\text { PreC }}$ \\
\hline \multirow[t]{6}{*}{$\mathrm{TC}(\mathrm{mg} / \mathrm{g})$} & 98 & 87 & $<37$ & $>$ & $>$ & & & & & 431 & $<$ \\
\hline & 14 & 13 & & & & & & & & 122 & \\
\hline & 115 & 110 & & & & & & & & $\mathrm{PM}_{1}$ & \\
\hline & & & & & & & & & & 125 & $<$ \\
\hline & & & & & & & & & & 8 & \\
\hline & & & & & & & & & & $\mathrm{TRD}<37$ & \\
\hline \multirow[t]{3}{*}{ Fluo $(\mu \mathrm{g} / \mathrm{g})$} & 0.24 & 0.13 & $<37$ & $>$ & $>$ & 3.4 & 30.0 & 2.5 & 20.9 & & \\
\hline & 0.51 & 0.25 & & & & & & & & & \\
\hline & 2.28 & 1.18 & & & & & & & & & \\
\hline \multirow[t]{3}{*}{ Py $(\mu \mathrm{g} / \mathrm{g})$} & 0.23 & 0.13 & $<37$ & $>$ & $>$ & 3.4 & 23.0 & 2.6 & 16.9 & & \\
\hline & 0.39 & 0.20 & & & & & & & & & \\
\hline & 1.75 & 0.95 & & & & & & & & & \\
\hline \multirow[t]{3}{*}{$\mathrm{BaA}(\mu \mathrm{g} / \mathrm{g})$} & 0.05 & 0.03 & $<37$ & $>$ & $>$ & 3.7 & 40.9 & 2.9 & 31.2 & 43 & $<$ \\
\hline & 0.14 & 0.08 & & & & & & & & 28 & \\
\hline & 0.62 & 0.35 & & & & & & & & $\mathrm{PM}_{1}$ & \\
\hline \multirow[t]{3}{*}{$\mathrm{BbF}(\mu \mathrm{g} / \mathrm{g})$} & 0.08 & 0.05 & $<37$ & $>$ & $>$ & 3.2 & 22.0 & 4.8 & 33.1 & 59 & $<$ \\
\hline & 0.13 & 0.08 & & & & & & & & 25 & \\
\hline & 0.61 & 0.37 & & & & & & & & $\mathrm{PM}_{1}$ & \\
\hline \multirow[t]{3}{*}{$\mathrm{BkF}(\mu \mathrm{g} / \mathrm{g})$} & 0.04 & 0.02 & $<37$ & $>$ & $>$ & 2.7 & 20.7 & 4.7 & 33.4 & 32 & $<$ \\
\hline & 0.07 & 0.04 & & & & & & & & 14 & \\
\hline & 0.30 & 0.19 & & & & & & & & $\mathrm{PM}_{1}$ & \\
\hline \multirow[t]{3}{*}{$\mathrm{BaP}(\mu \mathrm{g} / \mathrm{g})$} & 0.07 & 0.04 & $<37$ & $>$ & $>$ & 2.6 & 22.7 & 4.4 & 37.2 & 56 & $<$ \\
\hline & 0.15 & 0.09 & & & & & & & & 27 & \\
\hline & 0.66 & 0.42 & & & & & & & & $\mathrm{PM}_{1}$ & \\
\hline \multirow[t]{3}{*}{ BghiP $(\mu \mathrm{g} / \mathrm{g})$} & 0.20 & 0.13 & $<37$ & $>$ & $>$ & 5.7 & 20.1 & 14.0 & 43.4 & 60 & $<$ \\
\hline & 0.18 & 0.11 & & & & & & & & 26 & \\
\hline & 0.83 & 0.49 & & & & & & & & $\mathrm{PM}_{1}$ & \\
\hline Ind 123cdP $(\mu \mathrm{g} /$ & 0.08 & 0.07 & $<37$ & $>$ & $>$ & 1.2 & 4.6 & 1.4 & 4.0 & 41 & $<$ \\
\hline g) & 0.07 & 0.04 & & & & & & & & 24 & \\
\hline & 0.35 & 0.23 & & & & & & & & $\mathrm{PM}_{1}$ & \\
\hline $\mathrm{Li}(\mu \mathrm{g} / \mathrm{g})$ & 15 & 11 & $<37$ & $<$ & $* * * *$ & 0.2 & 0.3 & 0.2 & 0.3 & & \\
\hline & 4 & 3 & & & & & & & & & \\
\hline & 22 & 16 & & & & & & & & & \\
\hline $\mathrm{Na}(\mathrm{mg} / \mathrm{g})$ & 6 & 7 & $37-63$ & $>$ & $>$ & 0.3 & 1.2 & 0.4 & 1.7 & 5 & $* * * *$ \\
\hline & 7 & 7 & & & & & & & & 1 & \\
\hline & 35 & 38 & & & & & & & & $\mathrm{TRD}<37$ & \\
\hline $\mathrm{Mg}(\mathrm{mg} / \mathrm{g})$ & 14 & 15 & $* * * *$ & $* * * *$ & $>$ & 2.3 & 3.8 & 3.1 & 5.2 & & \\
\hline & 5 & 5 & & & & & & & & & \\
\hline & 23 & 26 & & & & & & & & & \\
\hline $\mathrm{Al}(\mathrm{mg} / \mathrm{g})$ & 3 & 3 & $* * * *$ & $>$ & $>$ & 0.1 & 0.7 & 0.2 & 1.6 & & \\
\hline & 4 & 5 & & & & & & & & & \\
\hline & 17 & 22 & & & & & & & & & \\
\hline $\mathrm{S}(\mathrm{mg} / \mathrm{g})$ & 3.4 & 3.0 & $<37$ & $* * * *$ & $>$ & 2.5 & 2.9 & 2.6 & 3.1 & 8.6 & $<$ \\
\hline & 0.5 & 0.6 & & & & & & & & 0.5 & \\
\hline & 4.3 & 4.3 & & & & & & & & $\mathrm{TRD}<37$ & \\
\hline $\mathrm{K}(\mathrm{mg} / \mathrm{g})$ & 11 & 9 & $<37$ & $>$ & $>$ & 0.2 & 0.3 & 0.2 & 0.5 & 7 & $* * * *$ \\
\hline & 3 & 4 & & & & & & & & 1 & \\
\hline & 20 & 23 & & & & & & & & $\mathrm{TRD}_{<37}$ & \\
\hline $\mathrm{Ca}(\mathrm{mg} / \mathrm{g})$ & 113 & 110 & $* * * *$ & $>$ & $>$ & 1.9 & 2.3 & 2.2 & 2.8 & 144 & $* * * *$ \\
\hline & 19 & 19 & & & & & & & & 14 & \\
\hline & 150 & 135 & & & & & & & & TRD $<37$ & \\
\hline $\mathrm{Sc}(\mu \mathrm{g} / \mathrm{g})$ & 1.3 & 1.1 & $<37$ & $>$ & $>$ & 0.2 & 0.4 & 0.4 & 1.2 & 1.1 & $* * * *$ \\
\hline & 0.4 & 0.7 & & & & & & & & 0.2 & \\
\hline & 2.4 & 3.6 & & & & & & & & $\mathrm{TRD}<37$ & \\
\hline $\mathrm{Ti}(\mathrm{mg} / \mathrm{g})$ & 4.0 & 3.8 & $<37$ & $* * * *$ & $* * * *$ & 0.3 & 0.5 & 0.4 & 0.7 & 3.2 & $* * * *$ \\
\hline & 0.9 & 0.9 & & & & & & & & 0.3 & \\
\hline & 6.7 & 6.5 & & & & & & & & $\mathrm{TRD}<37$ & \\
\hline $\mathrm{V}(\mu \mathrm{g} / \mathrm{g})$ & 57 & 43 & $<37$ & $<$ & $>$ & 0.3 & 0.4 & 0.4 & 0.5 & 89 & $<$ \\
\hline & 8 & 10 & & & & & & & & 8 & \\
\hline & 72 & 70 & & & & & & & & $\mathrm{TRD}<37$ & \\
\hline $\mathrm{Cr}(\mu \mathrm{g} / \mathrm{g})$ & 200 & 142 & $<37$ & $* * * *$ & $>$ & 1.1 & 2.2 & 1.1 & 3.3 & 959 & $<$ \\
\hline & 101 & 85 & & & & & & & & 484 & \\
\hline & 442 & 405 & & & & & & & & $\mathrm{TRD}<37$ & \\
\hline $\mathrm{Mn}(\mu \mathrm{g} / \mathrm{g})$ & 735 & 578 & $<37$ & $* * * *$ & $>$ & 0.6 & 1.0 & 0.6 & 1.0 & 1377 & $<$ \\
\hline & 234 & 173 & & & & & & & & 230 & \\
\hline & 1309 & 913 & & & & & & & & $\mathrm{TRD}_{<37}$ & \\
\hline $\mathrm{Fe}(\mathrm{mg} / \mathrm{g})$ & 11 & 9 & $<37$ & $* * * *$ & $* * * *$ & 0.2 & 0.4 & 0.3 & 1.0 & 28 & $<$ \\
\hline & 3 & 6 & & & & & & & & 7 & \\
\hline & 19 & 33 & & & & & & & & $\mathrm{TRD}<37$ & \\
\hline
\end{tabular}




\begin{tabular}{|c|c|c|c|c|c|c|c|c|c|c|c|}
\hline & $\begin{array}{l}\overline{R D<37} \\
\mathrm{SD}<37 \\
\mathrm{MAX}_{<37}\end{array}$ & $\begin{array}{l}\overline{R D}_{37-63} \\
\mathrm{SD}_{37-63} \\
\mathrm{MAX}_{37-63}\end{array}$ & $\mathrm{HC}$ & $\frac{\# 20<37 ?}{\text { landside }<37}$ & $\frac{\# 20_{37-63} ?}{\text { landside }_{37-63}}$ & $\overline{E F<37}$ & $\begin{array}{l}\mathrm{MAX} \\
\mathrm{EF}<37\end{array}$ & $\overline{E F_{37-63}}$ & $\begin{array}{l}\mathrm{MAX} \\
\mathrm{EF}_{37-63}\end{array}$ & $\begin{array}{l}\overline{\text { PreC }} \\
\text { SDPreC } \\
\text { Previous } \\
\text { Campaign }\end{array}$ & $\overline{R D_{<37}} ? \overline{\text { PreC }}$ \\
\hline \multirow[t]{3}{*}{ Co $(\mu \mathrm{g} / \mathrm{g})$} & 9 & 7 & $<37$ & $>$ & $>$ & 0.5 & 1.0 & 0.5 & 1.0 & 13 & $* * * *$ \\
\hline & 3 & 3 & & & & & & & & 5 & \\
\hline & 18 & 14 & & & & & & & & $\mathrm{TRD}<37$ & \\
\hline \multirow[t]{3}{*}{$\mathrm{Ni}(\mu \mathrm{g} / \mathrm{g})$} & 41 & 33 & $<37$ & $>$ & $>$ & 0.6 & 1.1 & 0.8 & 2.3 & 113 & $<$ \\
\hline & 15 & 19 & & & & & & & & 27 & \\
\hline & 79 & 94 & & & & & & & & $\mathrm{TRD}_{<37}$ & \\
\hline \multirow[t]{3}{*}{$\mathrm{Cu}(\mu \mathrm{g} / \mathrm{g})$} & 295 & 228 & $<37$ & $>$ & $>$ & 3.4 & 12.5 & 3.4 & 12.1 & 1814 & $<$ \\
\hline & 325 & 250 & & & & & & & & 744 & \\
\hline & 1190 & 930 & & & & & & & & $\mathrm{TRD}<37$ & \\
\hline \multirow[t]{3}{*}{$\mathrm{Zn}(\mathrm{mg} / \mathrm{g})$} & 1.7 & 1.5 & $<37$ & $>$ & $>$ & 6.8 & 53.5 & 3.8 & 40.0 & 1.5 & $* * * *$ \\
\hline & 3.3 & 3.7 & & & & & & & & 0.5 & \\
\hline & 14.5 & 16.4 & & & & & & & & $\mathrm{TRD}<37$ & \\
\hline \multirow[t]{3}{*}{ As $(\mu \mathrm{g} / \mathrm{g})$} & 5.9 & 4.0 & $<37$ & $* * * *$ & $>$ & 0.2 & 0.3 & 0.1 & 0.3 & 6.7 & $* * * *$ \\
\hline & 1.6 & 1.3 & & & & & & & & 3.5 & \\
\hline & 8.7 & 6.8 & & & & & & & & $\mathrm{TRD}<37$ & \\
\hline \multirow[t]{3}{*}{ Mo $(\mu \mathrm{g} / \mathrm{g})$} & 7 & 7 & $<37$ & $>$ & $>$ & 8.6 & 35.7 & 9.7 & 64.0 & 29 & $<$ \\
\hline & 7 & 9 & & & & & & & & 10 & \\
\hline & 29 & 42 & & & & & & & & $\mathrm{TRD}_{<37}$ & \\
\hline \multirow[t]{3}{*}{$\mathrm{Ag}(\mu \mathrm{g} / \mathrm{g})$} & 1.0 & 0.7 & $<37$ & $>$ & $>$ & 0.2 & 1.0 & 0.3 & 2.1 & 1.9 & $* * * *$ \\
\hline & 1.1 & 1.3 & & & & & & & & 0.7 & \\
\hline & 4.4 & 5.1 & & & & & & & & $\mathrm{TRD}_{<37}$ & \\
\hline \multirow[t]{3}{*}{$\mathrm{Cd}(\mu \mathrm{g} / \mathrm{g})$} & 1.2 & 0.7 & $<37$ & $>$ & $>$ & 1.0 & 3.3 & 1.1 & 5.5 & 2.7 & $* * * *$ \\
\hline & 1.3 & 1.0 & & & & & & & & 0.8 & \\
\hline & 4.5 & 4.0 & & & & & & & & $\mathrm{TRD}_{<37}$ & \\
\hline \multirow[t]{3}{*}{$\mathrm{Sb}(\mu \mathrm{g} / \mathrm{g})$} & 21 & 13 & $<37$ & $* * * *$ & $* * * *$ & 6.0 & 30.4 & 5.2 & 28.4 & 51 & $* * * *$ \\
\hline & 22 & 14 & & & & & & & & 52 & \\
\hline & 97 & 63 & & & & & & & & $\mathrm{TRD}<37$ & \\
\hline \multirow[t]{3}{*}{$\mathrm{Ba}(\mu \mathrm{g} / \mathrm{g})$} & 300 & 228 & $<37$ & $>$ & $>$ & 0.3 & 0.5 & 0.3 & 0.5 & 379 & $* * * *$ \\
\hline & 67 & 49 & & & & & & & & 122 & \\
\hline & 467 & 341 & & & & & & & & $\mathrm{TRD}<37$ & \\
\hline \multirow[t]{3}{*}{$\mathrm{Pb}(\mu \mathrm{g} / \mathrm{g})$} & 102 & 98 & $* * * *$ & $* * * *$ & $* * * *$ & 3.5 & 10.7 & 2.0 & 5.9 & 678 & $<$ \\
\hline & 72 & 67 & & & & & & & & 127 & \\
\hline & 289 & 231 & & & & & & & & $\mathrm{TRD}_{<37}$ & \\
\hline \multirow[t]{3}{*}{$\mathrm{U}(\mu \mathrm{g} / \mathrm{g})$} & 2.3 & 1.6 & $<37$ & $<$ & $>$ & 0.3 & 0.5 & 0.4 & 0.5 & & \\
\hline & 0.2 & 0.3 & & & & & & & & & \\
\hline & 2.6 & 2.7 & & & & & & & & & \\
\hline \multirow[t]{3}{*}{ PLI } & 2.3 & 2.3 & & & & & & & & & \\
\hline & 1.0 & 1.3 & & & & & & & & & \\
\hline & 6.2 & 7.4 & & & & & & & & & \\
\hline
\end{tabular}

With:

$\overline{R D<37}=$ average concentration of samples (\#1, ..., \#20) with particle size $<37 \mu \mathrm{m}$.

$\mathrm{SD}<37=$ standard deviation of $\frac{R D<37}{R D_{1}}$

MAX $<37=$ highest concentration of samples $(\# 1, \ldots, \# 20)$ with particle size $<37 \mu \mathrm{m}$.

$\overline{R D_{37-63}}=$ average concentration of samples $(\# 1, \ldots, \# 20)$ with particle size $37-63 \mu \mathrm{m}$.

$\mathrm{SD}_{37-63}=$ standard deviation of $\overline{R D_{37-63}}$.

MAX $_{37-63}=$ highest concentration of samples (\#1, ..., \#20) with particle size 37-63 $\mu \mathrm{m}$.

$\mathrm{HC}=$ Higher Concentration in the fraction $(<37 \mu \mathrm{m}$ or $37-63 \mu \mathrm{m})$.

$\overline{\text { landside }<37}=$ average concentration of samples $(\# 1, \ldots$, \#19) with particle size $<37 \mu \mathrm{m}$.

$\overline{\text { landside }_{37-63}}=$ average concentration of samples (\#1, ..., \#19) with particle size 37-63 $\mu \mathrm{m}$.

$\overline{E F<37}=$ average values of $\mathrm{EF}$ of samples $(\# 1, \ldots, \# 20)$ with particle size $<37 \mu \mathrm{m}$.

MAX EF $<37=$ highest EF of samples $(\# 1, \ldots$, \#20) with particle size $<37 \mu \mathrm{m}$.

$\overline{E F_{37-63}}=$ average values of $\mathrm{EF}$ of samples $(\# 1, \ldots, \# 20)$ with particle size $37-63 \mu \mathrm{m}$.

MAX $\mathrm{EF}_{37-63}=$ highest EF of samples $(\# 1, \ldots, \# 20$ ) with particle size $37-63 \mu \mathrm{m}$.

$\overline{\mathrm{PreC}}=$ average concentration of the Previous Campaign.

$\mathrm{SDPreC}=$ standard deviation of $\overline{P r e C}$.

$\mathrm{PM}_{1}=$ previous campaign of $\mathrm{PM}_{1}$ collected in traffic area (Valotto and Varin, 2016).

$\mathrm{TRD}<37$ = previous campaign of Road Dust with particle size $<37 \mu \mathrm{m}$ collected in traffic area (Valotto et al., 2015).

concentrations of $\mathrm{BaA}, \mathrm{BbF}$ of fine fraction, and $\mathrm{BaP}, \mathrm{Sb}, \mathrm{Cr}$ of both fractions are higher than the respective SSLs of ingestion + dermal intake for some scenarios. Finally, only the highest concentration of $\mathrm{Cr}$ of both fractions are higher than the SSLs related to the inhalation of fugitive particulates for residential scenario.

\section{Discussion}

PC1 and PC2 account for about 36\% and 26\% of total explained variance, respectively. Although they are characterized by significantly different loading shapes, both allow to highlight the differences between fine/coarse fractions of samples collected in landside $(\# 2, \ldots$, \#19), and between landside/airside samples as shown in Figs. S6, S7 and S11 of supplementary materials. We decided to merge both fractions because the interpretation of the few significant PCs calculated from fine or coarse sub-samples alone are not straightforward, likely due to the low number of samples (especially compared to the high number of variables).

PC1 shows significant high positive loadings for particle sizes lower than $40 \mu \mathrm{m}$ and for most of the pollutants. In particular, Co, Cd, Ba, U 
$\mathrm{RD}_{<37}$
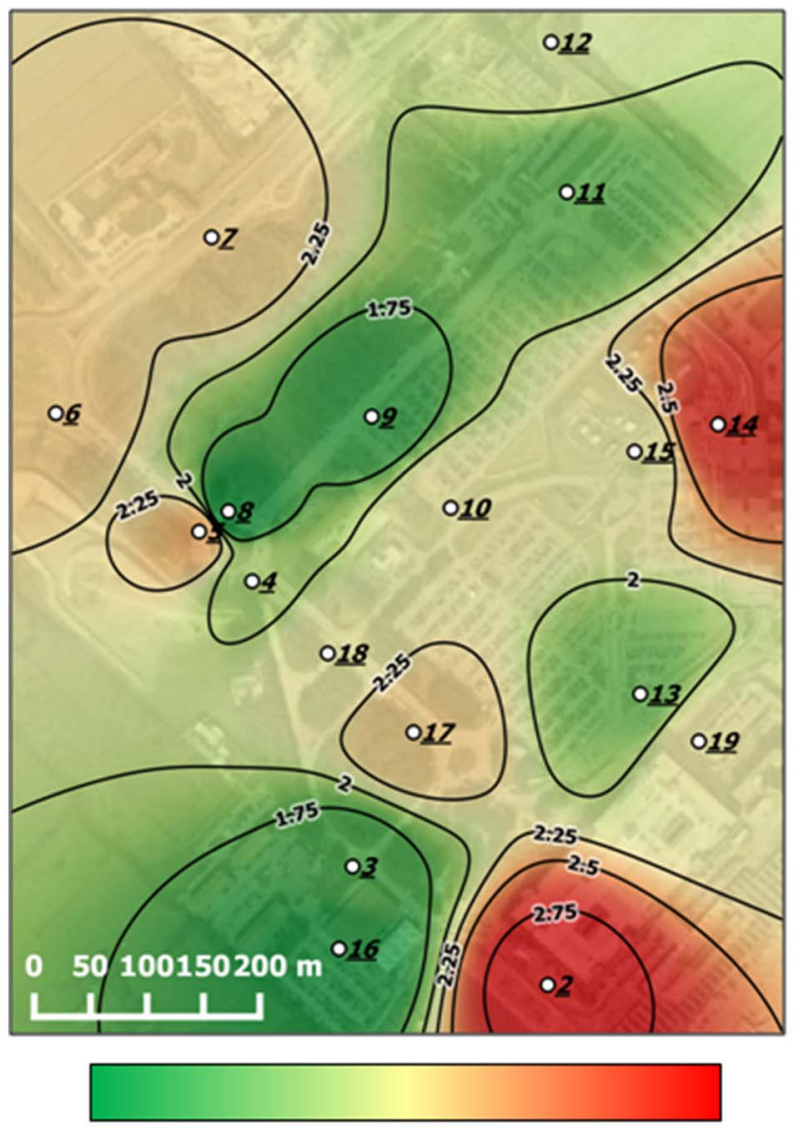

1.6
2.2
2.7
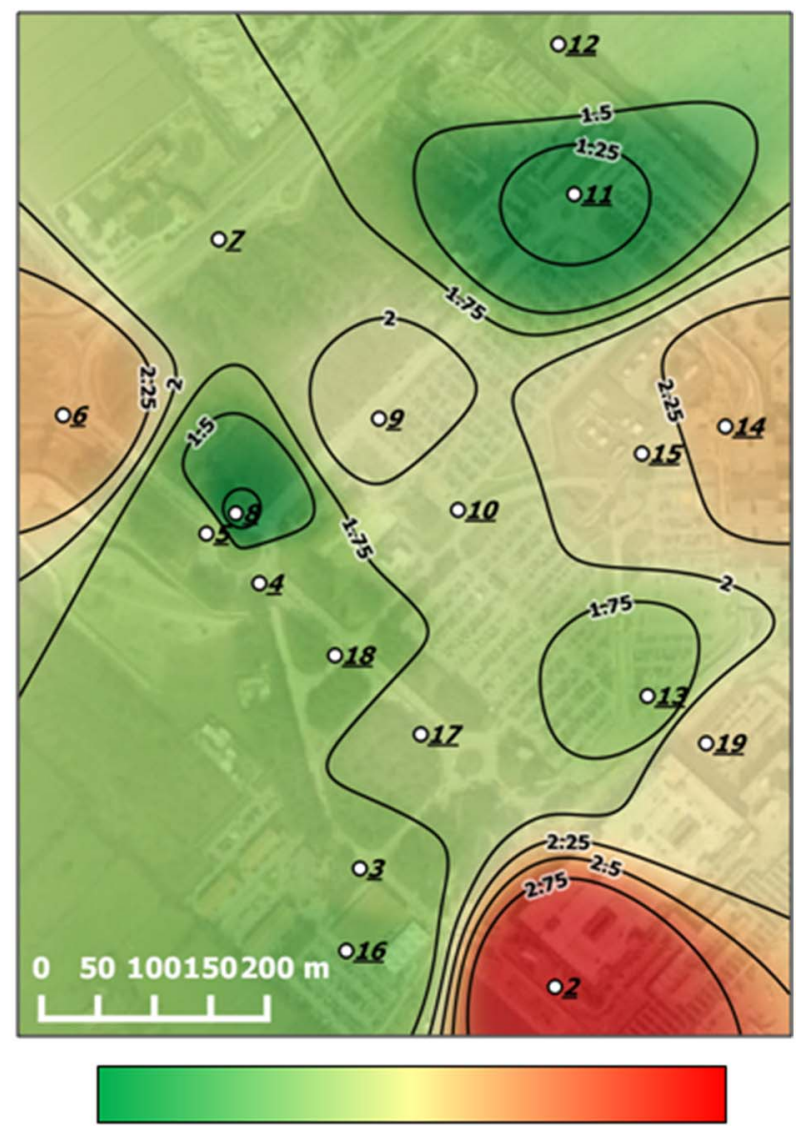

1.3

2.9

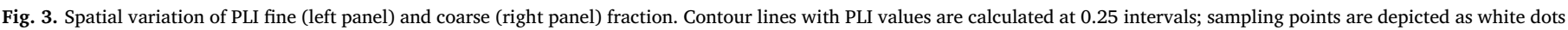
with underlined labels.

are characterized by the highest values. Instead, particle sizes higher than $40 \mu \mathrm{m}$ show significant negative values. Fine sub-samples show positive scores because (in addition to the obvious contribution provided by the loadings related to the particle sizes) they are characterized by higher values of almost all pollutants compared to the coarse sub-samples, as shown in the Fig. S1 of supplementary materials. For the note, $\mathrm{Cd}$ and $\mathrm{U}$ are among the pollutants significantly more concentrated in the fine fraction. Both fractions of sample collected in airside (\#20) show highest positive scores because, on average, they are characterized by the highest concentrations as shown in the Figs. S2 and S4 of supplementary materials. In this view we suggest as label for this PC "general difference between fine/coarse and airside/landside samples".

Likewise PC1, PC2 shows positive and negative loadings for fine $(<30 \mu \mathrm{m})$ and coarse fractions $(>40 \mu \mathrm{m})$, respectively. Otherwise, it is characterized by high negative values for several pollutants (less than PC1). Specifically, PAHs (except BghiP), Na, $\mathrm{Al}$ and $\mathrm{Zn}$ show the lowest loadings. Alike PC1, fine and coarse samples show positive and negative scores, respectively. Instead, both fraction of airside sample (\#20) are characterized by the highest negative scores due to their highest concentrations, especially for Fluo, Py, BaA, BbF, BkF, BaP, Na, Al and $\mathrm{Zn}$ as shown in Fig. S2 of supplementary materials.

In urban and industrialized areas the dominant source of RD particles rich in PAHs are the vehicular traffic (fuel combustion and tire wear), the oil combustion and refining, the coal and coke combustion, the bitumen and asphalt production, and the biomass burning (e.g.: Fang et al., 2004; Dong and Lee, 2009; Majumdar et al., 2016 and references therein). On average, RD samples show high EF values for these compounds; moreover, it is interesting to note that the fine fraction shows the higher EF for PAHs with low molecular weight, instead the coarse fraction is characterized by higher values for PAHs with high molecular weight. According with Dong and Lee (2009) and Zhao et al. (2009), PAHs are significantly more concentrated in the fine fraction of RD (Fig. S1) likely due to the high specific surface of particles which promotes the bonding of these compounds. The same pattern was noticed for atmospheric particulate collected in very different worldwide locations (e.g.: Bi et al., 2005; Ladji et al., 2009; Zhang et al., 2016) although the significantly higher concentrations compared to those of $\mathrm{RD}$ at issue. For the note, even the PAHs concentrations of $\mathrm{PM}_{1}$ collected in a traffic area near the Venice airport (Valotto et al., 2017a) are significantly higher than those of RD at issue as shown in Fig. S5 of supplementary materials. In addition to the particle size distributions of two matrices, this outline is probably related to the different residence time and the relative photochemical degradation process affecting them (e.g.: Behymer and Hites, 1985; Kamens et al., 1988). Indeed, $\mathrm{PM}_{1}$ was sampled near a busy highway where freshly emitted particles could be reasonably collected; instead, $\mathrm{RD}$ is composed by a significant amount of aged particle accumulated on road surface. The highest PAHs concentrations of both fractions of airside sample (\#20), some of them are higher than the respective SSLs 
Table 3

Loadings, explained and cumulative variance of PCs identified with Krzanowski crossvalidation method. For each PC, the 15 highest absolute loading values (33\% of the variables) are shown in bold.

\begin{tabular}{|c|c|c|c|c|c|}
\hline & PC1 & PC2 & PC3 & PC4 & PC5 \\
\hline Explained variance (\%) & 36 & 26 & 10 & 8 & 5 \\
\hline Cumulative variance (\%) & 36 & 62 & 72 & 80 & 85 \\
\hline$<1 \mu \mathrm{m}$ & 0.69 & 0.69 & -0.10 & -0.06 & -0.08 \\
\hline $1-5 \mu \mathrm{m}$ & 0.61 & 0.71 & -0.12 & 0.06 & -0.17 \\
\hline $5-10 \mu \mathrm{m}$ & 0.65 & 0.69 & -0.11 & 0.00 & -0.15 \\
\hline $10-20 \mu \mathrm{m}$ & 0.75 & 0.64 & -0.11 & -0.02 & 0.01 \\
\hline $20-30 \mu \mathrm{m}$ & 0.81 & 0.54 & -0.13 & 0.00 & 0.12 \\
\hline $30-40 \mu \mathrm{m}$ & 0.70 & 0.06 & -0.16 & 0.02 & 0.39 \\
\hline $40-50 \mu \mathrm{m}$ & -0.75 & -0.62 & 0.11 & -0.01 & 0.04 \\
\hline $50-60 \mu \mathrm{m}$ & -0.79 & -0.59 & 0.12 & -0.01 & -0.01 \\
\hline $60-70 \mu \mathrm{m}$ & -0.80 & -0.58 & 0.13 & 0.00 & -0.05 \\
\hline $70-80 \mu \mathrm{m}$ & -0.79 & -0.59 & 0.13 & 0.01 & -0.07 \\
\hline $80-90 \mu \mathrm{m}$ & -0.77 & -0.60 & 0.14 & 0.02 & -0.10 \\
\hline $90-100 \mu \mathrm{m}$ & -0.74 & -0.62 & 0.14 & 0.03 & -0.14 \\
\hline$>100 \mu \mathrm{m}$ & -0.54 & -0.65 & 0.14 & 0.08 & -0.24 \\
\hline TC & 0.48 & 0.00 & -0.10 & -0.67 & 0.32 \\
\hline Fluo & 0.62 & -0.71 & -0.26 & -0.03 & 0.04 \\
\hline Py & 0.64 & -0.68 & -0.28 & -0.08 & -0.06 \\
\hline $\mathrm{BaA}$ & 0.59 & -0.74 & -0.25 & -0.02 & 0.04 \\
\hline $\mathrm{BbF}$ & 0.63 & -0.70 & -0.28 & -0.01 & -0.01 \\
\hline $\mathrm{BkF}$ & 0.60 & -0.73 & -0.27 & -0.03 & -0.02 \\
\hline $\mathrm{BaP}$ & 0.59 & -0.74 & -0.27 & -0.03 & -0.02 \\
\hline BghiP & 0.60 & -0.51 & -0.37 & 0.02 & -0.27 \\
\hline $\mathrm{Li}$ & 0.42 & 0.43 & 0.02 & 0.36 & -0.42 \\
\hline $\mathrm{Na}$ & 0.50 & -0.82 & -0.19 & 0.08 & -0.05 \\
\hline $\mathrm{Mg}$ & 0.20 & -0.26 & 0.47 & -0.42 & -0.19 \\
\hline $\mathrm{Al}$ & 0.55 & -0.78 & -0.08 & 0.04 & -0.06 \\
\hline$S$ & 0.52 & -0.06 & -0.01 & -0.76 & 0.11 \\
\hline K & 0.60 & -0.53 & -0.29 & 0.38 & -0.22 \\
\hline $\mathrm{Ca}$ & 0.30 & -0.29 & 0.01 & -0.79 & 0.09 \\
\hline Sc & 0.62 & -0.47 & 0.00 & 0.38 & -0.11 \\
\hline $\mathrm{Ti}$ & 0.05 & 0.15 & 0.07 & 0.33 & 0.67 \\
\hline $\mathrm{V}$ & 0.62 & 0.32 & 0.11 & -0.18 & 0.02 \\
\hline $\mathrm{Cr}$ & 0.48 & 0.07 & 0.58 & -0.36 & -0.40 \\
\hline Mn & 0.43 & 0.19 & 0.29 & -0.52 & -0.53 \\
\hline $\mathrm{Fe}$ & 0.36 & -0.05 & 0.78 & 0.16 & -0.23 \\
\hline Co & 0.65 & -0.18 & 0.49 & 0.23 & 0.31 \\
\hline $\mathrm{Ni}$ & 0.58 & -0.32 & 0.54 & -0.03 & 0.28 \\
\hline $\mathrm{Cu}$ & 0.60 & -0.54 & 0.49 & -0.02 & 0.04 \\
\hline $\mathrm{Zn}$ & 0.58 & -0.75 & -0.07 & 0.04 & 0.09 \\
\hline As & 0.56 & 0.22 & 0.04 & 0.67 & -0.34 \\
\hline Mo & 0.39 & -0.31 & 0.76 & -0.14 & 0.06 \\
\hline $\mathrm{Ag}$ & 0.52 & -0.46 & 0.00 & -0.03 & -0.13 \\
\hline $\mathrm{Cd}$ & 0.65 & -0.47 & 0.32 & 0.17 & 0.29 \\
\hline $\mathrm{Sb}$ & 0.25 & 0.19 & 0.66 & 0.03 & -0.01 \\
\hline $\mathrm{Ba}$ & 0.78 & -0.10 & 0.18 & 0.32 & -0.14 \\
\hline $\mathrm{Pb}$ & 0.20 & -0.12 & 0.53 & 0.50 & 0.31 \\
\hline $\mathrm{U}$ & 0.81 & 0.36 & 0.11 & 0.11 & 0.04 \\
\hline
\end{tabular}

of ingestion + dermal intake of some receptors (Figs. 4, S12), are likely related to fuel spills during aircraft refueling.

$\mathrm{Na}$ is a typical tracer of sea spray contribution (Valotto et al., 2015). Due to the proximity of the sampling sites at issue (included the control soil sample \#21) with the Venice lagoon, this element is characterized by low EF values (Fig. S3). It is the only one element significantly more concentrated in the coarse fraction (Table 2 and Fig. S1) and the highest concentrations were revealed in the airside sample (\#20, Fig. S2) likely due to the use of anti-icing salt in the taxiway and airport apron, and to a lesser extent due to the greater closeness to the lagoon compared to the other RD samples.

$\mathrm{RD}$ particles $\mathrm{Al}$ rich typically originate from surrounding soils (Gunawardana et al., 2012) indeed it is often used as normalization element for EF evaluations (e.g.: Cesari et al., 2012 and references therein). However, in the last two decades the vehicular traffic is an additional source of this element because aluminium alloys have been increasingly adopted to reduce the weight of vehicles (Miller et al., 2000; Fujiwara et al., 2011b). As regards the landside RD samples we can claim that $\mathrm{Al}$ have mainly crustal origin because the low EF values
(Fig. S3). Instead the high concentrations of airside sample (Fig. S2) are likely related to the wear of aircraft components. Indeed, Aluminium alloys have been the primary material for the structural parts of aircraft for $>80$ years (Dursun and Soutis, 2014).

High $\mathrm{Zn}$ concentrations of $\mathrm{RD}$ matrix are often associated to tire wear emission source (Councell et al., 2004; Pant and Harrison, 2013; Valotto et al., 2015; Valotto et al., 2017b). Unlike $\mathrm{Na}$ and $\mathrm{Al}, \mathrm{Zn}$ is characterized by high EF values because all $\mathrm{RD}$ samples show elevated concentrations which are comparable with those of RD collected in a traffic area close to the airport (Valotto et al., 2015), as shown in Table 2 and Fig. S5 of supplementary materials. Instead, as $\mathrm{Na}$ and $\mathrm{Al}$ the highest concentrations of $\mathrm{Zn}$ were revealed in airside sample (\#20, still lower than all SSLs), in particular in the coarse fraction as shown in Table 2 and Fig. S2 of supplementary materials. Several works report that most of the particles emitted by tire wear traffic source are characterized by sizes significantly lower than $37 \mu \mathrm{m}$ (Wik and Dave, 2009; Mathissen et al., 2011). Then, assuming that the main source of $\mathrm{Zn}$ in the airside are the particles emitted by the wear of aircraft tires, it is conceivable that these are on average significantly larger than those of traffic source, probably due to the highest stresses to which wells are subjected, in particular during landing.

In this view we suggest as label for this PC2 "specific difference between fine/coarse and airside/landside samples".

PC3 account for about $10 \%$ of explained variance and shows high positive loadings ( $>0.5$ ) for $\mathrm{Cr}, \mathrm{Fe}, \mathrm{Mo}, \mathrm{Sb}$ and to a lesser extent $\mathrm{Mg}$, $\mathrm{Co}, \mathrm{Ni}, \mathrm{Cu}, \mathrm{Pb} . \mathrm{Sb}$ and $\mathrm{Cu}$ are tracer of brake pads wear (Hulskotte et al., 2007; Varrica et al., 2013; Grigoratos and Martini, 2015; Valotto et al., 2015; Valotto et al., 2017b), while Ni, Cr, and Mo in addition to Fe and C are typical steel constituent (Tomita and Okabayashi, 1985). Because the brake discs are made of steel, and $\mathrm{Mg}$ and Co were identified in brake dust (Grigoratos and Martini, 2015) we suggest as representative pollutant source of PC3 the "brake wear". Indeed, samples characterized by higher scores are both fractions of \#2 and \#14 which were collected at the end of two down ramps where brakes are typically most stressed. For the note these last two are among the landside samples characterized by the higher PLI values (Figs. 3 and S4), suggesting that the brake wear is a significant pollutant source in the monitored area. However, only the highest values of $\mathrm{Sb}$ and $\mathrm{Cr}$, which on average are more concentrated in the fine fractions, are higher than some SSLs (Figs. 4 and S12). Moreover, it is worth noting that Mo and Sb show high $\mathrm{EF}$, only $\mathrm{Cu}$ is significantly more concentrated in airside (suggesting an additional source of this element or a different composition of aircraft brakes compared to those of ground vehicles), and the concentrations of the representative elements of this PC are significantly lower (in particular $\mathrm{Cr}$, Mo, $\mathrm{Cu}$ and $\mathrm{Pb}$ ) than those of $\mathrm{RD}$ samples collected in a traffic area close to the airport, as shown in Table 2 and Figs. S1-S3, S5 of supplementary materials.

PC4 ( $8 \%$ explained variance) show significant positive and negative loadings for $\mathrm{As}, \mathrm{Pb}$ and $\mathrm{TC}, \mathrm{Mg}, \mathrm{S}, \mathrm{Ca}, \mathrm{Mn}$, respectively. $\mathrm{Pb}$ is a well assessed traffic tracer related to the fuel combustion, even though leaded fuel was legally banned in Italy since January 2002 (DPCM, 2001; Vecchi et al., 2007; Amato et al., 2009; Mori et al., 2015). Besides, As is a trace contaminant of different fuels (Brandão et al., 2006; Talebi and Abedi, 2005). Instead, the association TC-Mg-Ca-Mn is obviously related to carbonate compositions. These minerals are commonly found in atmospheric particulate and road dust samples, and are usually used as tracers for re-suspended soil dust, handling of construction materials and building projects (Lu et al., 2008; Yuan et al., 2008; Arsene et al., 2011; Bardelli et al., 2011; Cuccia et al., 2011; Jancsek-Turóczi et al., 2013; Valotto et al., 2015). In this work, the most likely sources of carbonate are the construction works related to the airport expansion, even if the wear of aggregates used in the asphalt concrete for paving the road and the soil dust resuspension cannot be ruled out. According with Valotto et al. (2015) and Zannoni et al. (2016), the high negative loading of sulfur in this PC is likely related to the reaction between acid rains and carbonate particles which are 


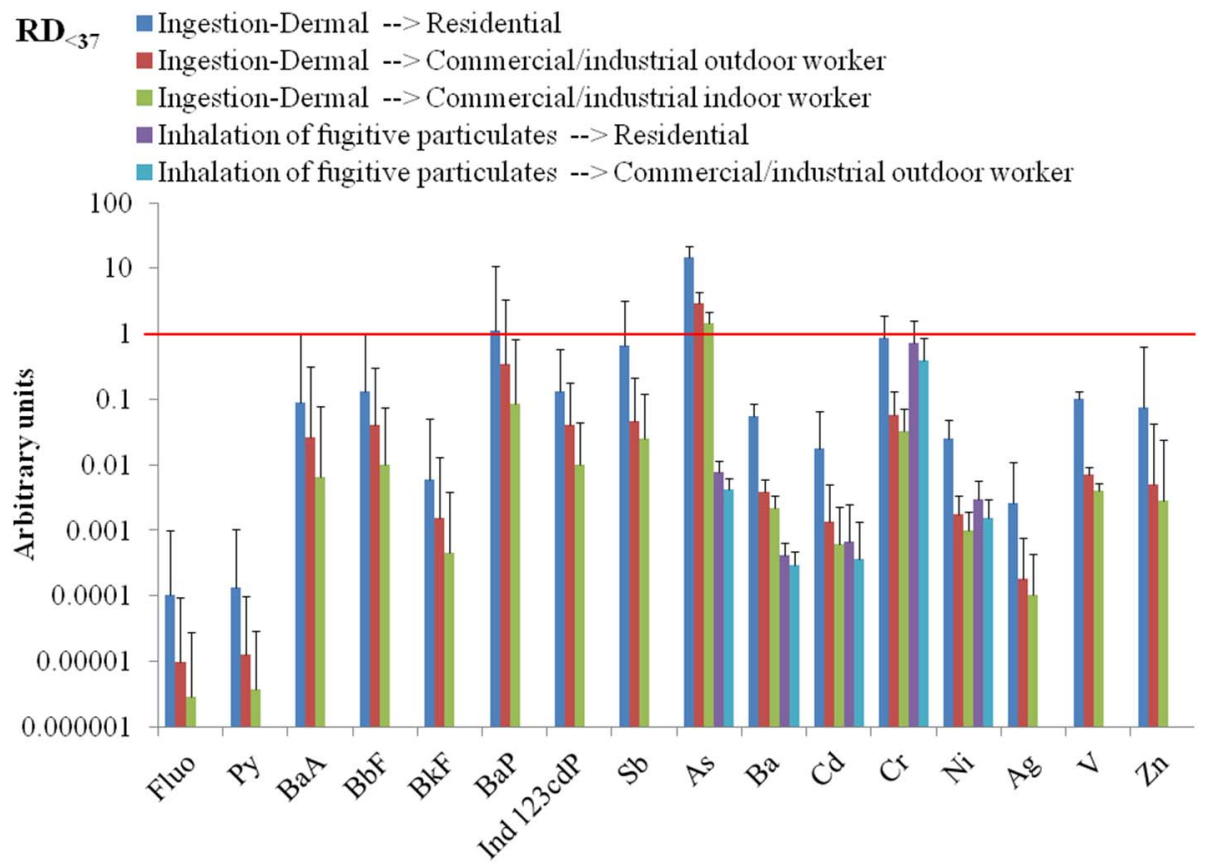

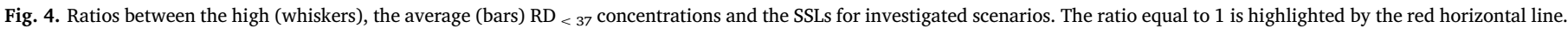

covered with a thin layer of gypsum. For the note, samples characterized by higher positive and negative scores were collected near the fuel aircraft storage and close to construction sites or uncovered soils, respectively. Accordingly, because this PC allows to discriminate samples characterized by high contributions of two different pollutant sources, the appropriate label of this PC could be "construction vs fuel". Finally, it is worth noting that the representative elements of this PC shows low $\mathrm{EF}$, As (on average, more concentrated in the fine fraction) is the most critical elements as regards the SSLs, and although the airside sample (\#20) show low scores it is anyway characterized by high concentrations of As.

PC5 (5\% explained variance) show positive and mildly negative loadings just for $\mathrm{Ti}, 30-40 \mu \mathrm{m}$ and $\mathrm{Mn}$, respectively. Titanium alloys are employed in aerospace and, to a lesser extent, in automotive industry due to their highest resistance to extreme stresses (e.g.: Boyer, 1996; Schauerte, 2003; Saito, 2004; Boyer and Briggs, 2005; Kainer, 2006). Also, $\mathrm{Ti}$ is commonly used in white paints in the form of $\mathrm{TiO}_{2}$ and in brake pads, especially in metallic-ceramic compounds (ANAS, 2007; Zannoni et al., 2016). Because samples characterized by highest scores were collected inside parking areas and airside sample does not show concentration higher than landside samples (Fig. S2), we can claim with reasonable confidence that the main source of particles Ti rich with size $30-40 \mu \mathrm{m}$ in the monitored area is the wear of the white road lines which, for the note, are denser in car parks than streets. Indeed, the Ti average concentration of RD collected in a traffic area (without parks) close to the airport is lower than that of RD sampled in Venice airport (Fig. S5). In this view we suggest as representative pollutant source of this PC the "white paint wear". Finally, it is worth stressing that parks are the areas characterized by lower PLI as shown in Fig. 3.

As regards the risk assessment it is worth noting that most of the concentrations (average and highest values) above SSLs are related to residential scenario, which is quite inapt for the monitored area, although some housing areas are not far away to the airport. Instead, if industrial scenario is taken into account, just the average concentration of As overcomes the SSLs for ingestion + dermal intake pathways of indoor and outdoor worker receptors. However, it is worth remember that the SSLs at issue are defined for soil matrix which is quite different to $\mathrm{RD}$ samples probed in this and in several other works where risk assessments were performed. Therefore, it is mandatory to pursue this topics and create a guide which taken into account the peculiarities of $\mathrm{RD}$ matrix (e.g.: concentrations as a function of the particle sizes, total $\mathrm{RD}$ mass $\mathrm{m}^{-2}$, flow and type of traffic, wind speed, precipitations) for a more appropriate risk assessment.

\section{Conclusions}

In this work we performed a deep characterization and a preliminary risk assessment of road dust collected in the Venice international airport, highlighting the hot-spot areas and the differences between airside and landside sites. Considering the high number of workers and tourists which attend this airport and the ongoing works related to its enlargement, this research addresses a fundamental step for the protection of potential receptors and emphasizes the need to deep investigate this topic in this and other popular sites.

Results confirmed that road dust can be an important source of atmospheric particulate by re-suspension, and that it is also composed of particles originated by non-exhaust sources such as the brake, tire and road wear, and other local sources such as the activities related to construction sites and anti-icing safety procedures. Moreover, streets are the most polluted landside places; while road dust of airside area is significantly more concentrated in PAHs, $\mathrm{Na}, \mathrm{Al}, \mathrm{Cu}, \mathrm{Zn}, \mathrm{Ag}$, Cd. Finally, as regards the risk assessment, the most critical pollutants (in concern order) are: $\mathrm{As}, \mathrm{BaP}, \mathrm{Cr}, \mathrm{Sb}, \mathrm{BaA}$, and $\mathrm{BbF}$.

\section{Disclaimer}

The views expressed in this study are exclusively of the authors and may not reflect those of ARPAV.

\section{Acknowledgments}

Authors are grateful to SAVE Spa for the technical support to the samples collection.

\section{Appendix A. Supplementary data}

Supplementary data associated with this article can be found in the online version, at https://doi.org/10.1016/j.gexplo.2018.03.005. 
These data include the Google map of the most important areas described in this article.

\section{References}

Amato, F., Pandolfi, M., Viana, M., Querol, X., Alastuey, A., Moreno, T., 2009. Spatial and chemical patterns of PM10 in road dust deposited in urban environment. Atmos. Environ. 43 (9), 1650-1659.

Amato, F., Cassee, F.R., van der Gon, H.A.D., Gehrig, R., Gustafsson, M., Hafner, W., Harrison, R.M., Jozwicka, M., Kelly, F.J., Moreno, T., Prevot, A.S., Schaap, M., Sunyer, J., Querol, X., 2014. Urban air quality: the challenge of traffic non-exhaust emissions. J. Hazard. Mater. 275, 31-36.

Amato, F., Zandveld, P., Keuken, M., Jonkers, S., Querol, X., Reche, C., van der Gon, H.A.D., Schaap, M., 2016. Improving the modeling of road dust levels for Barcelona at urban scale and street level. Atmos. Environ. 125 (Part A), 231-242.

Arsene, C., Olariu, R.I., Zarmpas, P., Kanakidou, M., Mihalopoulos, N., 2011. Ion composition of coarse and fine particles in Iasi, north-eastern Romania: implications for aerosols chemistry in the area. Atmos. Environ. 45 (4), 906-916.

Assaeroporti, 2016. Associazione Italiana Gestori Aeroporti. http://www.assaeroporti. com/statistiche_201512/ (Available at, last accessed on 2016).

Azienda Nazionale Autonoma delle Strade (ANAS), Centro Sperimentale Stradale, 2007. Segnaletica Stradale Orizzontale: Normativa, Materiali, Caratteristiche Tecniche e Metodologie di Controllo. (in Italian).

Bardelli, F., Cattaruzza, E., Gonella, F., Rampazzo, G., Valotto, G., 2011. Characterization of road dust collected in Traforo del San Bernardo highway tunnel: Fe and Mn speciation. Atmos. Environ. 45 (35), 6459-6468.

Behymer, T.D., Hites, R.A., 1985. Photolysis of polycyclic aromatic hydrocarbons adsorbed on simulated atmospheric particulates. Environ. Sci. Technol. 19 (10), 1004-1006.

Bi, X., Sheng, G., Peng, P., Chen, Y., Fu, J., 2005. Size distribution of n-alkanes and polycyclic aromatic hydrocarbons (PAHs) in urban and rural atmospheres of Guangzhou, China. Atmos. Environ. 39 (3), 477-487.

Boyer, R., 1996. An overview on the use of titanium in the aerospace industry. Mater. Sci. Eng. A 213 (1), 103-114.

Boyer, R., Briggs, R., 2005. The use of titanium alloys in the aerospace industry. J. Mater. Eng. Perform. 14 (6), 681-685.

Brandão, G.P., de Campos, R.C., Luna, A.S., de Castro, E.V.R., de Jesus, H.C., 2006. Determination of arsenic in diesel, gasoline and naphtha by graphite furnace atomic absorption spectrometry using microemulsion medium for sample stabilization. Anal. Bioanal. Chem. 385 (8), 1562-1569.

Bukowiecki, N., Gehrig, R., Lienemann, P., Hill, M., Figi, R., Buchmann, B., Furger, M., Richard, A., Mohr, C., Weimer, S., et al., 2009. PM10 emission factors of abrasion particles from road traffic. Schweiz. Eidgenoss. 1268 (Available at: http://www.bafu.admin.ch/luft/00575/00578/index.html?lang1/4de).

Cesari, D., Contini, D., Genga, A., Siciliano, M., Elefante, C., Baglivi, F., Daniele, L., 2012. Analysis of raw soils and their re-suspended PM10 fractions: characterisation of source profiles and enrichment factors. Appl. Geochem. 27 (6), 1238-1246.

Chen, M., Pi, L., Luo, Y., Geng, M., Hu, W., Li, Z., Su, S., Gan, Z., Ding, S., 2016. Grain size distribution and health risk assessment of metals in outdoor dust in Chengdu, southwestern China. Arch. Environ. Contam. Toxicol. 70 (3), 534-543.

Councell, T.B., Duckenfield, K.U., Landa, E.R., Callender, E., 2004. Tire-wear particles as a source of zinc to the environment. Environ. Sci. Technol. 38 (15), 4206-4214.

Cuccia, E., Piazzalunga, A., Bernardoni, V., Brambilla, L., Fermo, P., Massabò, D., Molteni, U., Prati, P., Valli, G., Vecchi, R., 2011. Carbonate measurements in PM10 near the marble quarries of Carrara (Italy) by infrared spectroscopy (FT-IR) and source apportionment by positive matrix factorization (PMF). Atmos. Environ. 45 (35), 6481-6487.

Denby, B., Sundvor, I., Johansson, C., Pirjola, L., Ketzel, M., Norman, M., Kupiainen, K., Gustafsson, M., Blomqvist, G., Omstedt, G., 2013a. A coupled road dust and surface moisture model to predict non-exhaust road traffic induced particle emissions (NORTRIP). Part 1: road dust loading and suspension modelling. Atmos. Environ. 77, $283-300$.

Denby, B., Sundvor, I., Johansson, C., Pirjola, L., Ketzel, M., Norman, M., Kupiainen, K., Gustafsson, M., Blomqvist, G., Kauhaniemi, M., Omstedt, G., 2013b. A coupled road dust and surface moisture model to predict non-exhaust road traffic induced particle emissions (NORTRIP). Part 2: surface moisture and salt impact modelling. Atmos. Environ. 81, 485-503.

Dong, T.T., Lee, B.-K., 2009. Characteristics, toxicity, and source apportionment of polycylic aromatic hydrocarbons (PAHs) in road dust of Ulsan, Korea. Chemosphere $74(9), 1245-1253$.

DPCM, 2001. 23 novembre 2000, n.434-Regolamento recante recepimento della direttiva 98/70/CE relativa alla qualità della benzina e del combustibile diesel. Gazzetta Ufficiale della Repubblica Italiana (Published in, n. 25 del 31 gennaio).

Dursun, T., Soutis, C., 2014. Recent developments in advanced aircraft aluminium alloys. Mater. Des. 56, 862-871.

EMEP/EEA, 2016. Air Pollutant Emission Inventory Guidebook 2016: Technical Guidance to Prepare National Emission Inventories (1.A.3.b.vi-vii Road Tire and Brake Wear 2016, Available online). https://www.eea.europa.eu/publications/emep-eeaguidebook-2016.

Fang, G.-C., Chang, C.-N., Wu, Y.-S., Fu, P.P.-C., Yang, I.-L., Chen, M.-H., 2004. Characterization, identification of ambient air and road dust polycyclic aromatic hydrocarbons in central Taiwan, Taichung. Sci. Total Environ. 327 (1), 135-146.

Franco, V., Kousoulidou, M., Muntean, M., Ntziachristos, L., Hausberger, S., Dilara, P. 2013. Road vehicle emission factors development: a review. Atmos. Environ. 70,
84-97.

Fujiwara, F.G., GÃ $\tilde{3}^{3}$ ez, D.R., Dawidowski, L., Perelman, P., Faggi, A., 2011a. Metals associated with airborne particulate matter in road dust and tree bark collected in a megacity (Buenos Aires, Argentina). Ecol. Indic. 11 (2), 240-247.

Fujiwara, F., Rebagliati, R.J., Dawidowski, L., GÃ³mez, D., Polla, G., Pereyra, V., Smichowski, P., 2011b. Spatial and chemical patterns of size fractionated road dust collected in a megacitiy. Atmos. Environ. 45 (8), 1497-1505.

Grigoratos, T., Martini, G., 2014. Non-exhaust Traffic Related Emissions - Brake and Tire Wear PM; JRC Scientific and Policy Reports (Available online). http://publications. jrc.ec.europa.eu/repository/bitstream/111111111/31875/1/jrc89231-online \%20final\%20version\%202.pdf.

Grigoratos, T., Martini, G., 2015. Brake wear particle emissions: a review. Environ. Sci. Pollut. Res. 22 (4), 2491-2504.

Gunawardana, C., Goonetilleke, A., Egodawatta, P., Dawes, L., Kokot, S., 2012. Source characterisation of road dust based on chemical and mineralogical composition. Chemosphere 87 (2), 163-170.

Hulskotte, J., Denier van der Gon, H., Visschedijk, A., Schaap, M., 2007. Brake wear from vehicles as an important source of diffuse copper pollution. Water Sci. Technol. 56 (1), 223-231.

Jancsek-Turóczi, B., Hoffer, A., Nyiro-Kósa, I., Gelencsér, A., 2013. Sampling and characterization of resuspended and respirable road dust. J. Aerosol Sci. 65, 69-76.

Jolliffe, I., 2002. Principal Component Analysis. Wiley Online Library.

Kainer, K.U., 2006. Metal Matrix Composites: Custom-Made Materials for Automotive and Aerospace Engineering. John Wiley \& Sons.

Kamens, R.M., Guo, Z., Fulcher, J.N., Bell, D.A., 1988. The influence of humidity, sunlight, and temperature on the daytime decay of polyaromatic hydrocarbons on atmospheric soot particles. Environ. Sci. Technol. 22 (1), 103-108.

Kaufman, L., Rousseeuw, P.J., 2009. Finding Groups in Data: An Introduction to Cluster Analysis. Vol. 344 John Wiley \& Sons.

Kumar, P., Pirjola, L., Ketzel, M., Harrison, R.M., 2013. Nanoparticle emissions from 11 non-vehicle exhaust sources a review. Atmos. Environ. 67, 252-277.

Ladji, R., Yassaa, N., Balducci, C., Cecinato, A., Meklati, B.Y., 2009. Distribution of the solvent-extractable organic compounds in fine (PM1) and coarse (PM10) particles in urban, industrial and forest atmospheres of northern Algeria. Sci. Total Environ. 408 (2), 415-424.

Li, K., Liang, T., Wang, L., Yang, Z., 2015. Contamination and health risk assessment of heavy metals in road dust in Bayan Obo Mining Region in Inner Mongolia, North China. J. Geogr. Sci. 25 (12), 1439-1451.

Lu, S., Zheng, Y., Bai, S., 2008. A HRTEM/EDX approach to identification of the source of dust particles on urban tree leaves. Atmos. Environ. 42 (26), 6431-6441.

Majumdar, D., Rajaram, B., Meshram, S., Suryawanshi, P., Chalapati Rao, C.V., 2016. Worldwide distribution of polyclyclic aromatic hydrocarbons in urban road dust. Int. J. Environ. Sci. Technol. 1-24.

Marcopolodomani, 2016. http://www.marcopolodomani.it/progetto/ampliamentoaerostazione.html (Available at, last accessed on 2016).

Mathissen, M., Scheer, V., Vogt, R., Benter, T., 2011. Investigation on the potential generation of ultrafine particles from the tire-road interface. Atmos. Environ. 45 (34), 6172-6179.

Miller, W., Zhuang, L., Bottema, J., Wittebrood, A., Smet, P.D., Haszler, A., Vieregge, A., 2000. Recent development in aluminium alloys for the automotive industry. Mater. Sci. Eng. A 280 (1), 37-49.

Mori, J., Saebo, A., Hanslin, H.M., Teani, A., Ferrini, F., Fini, A., Burchi, G., 2015 Deposition of traffic related air pollutants on leaves of six evergreen shrub species during a Mediterranean summer season. Urban For. Urban Green. 14 (2), 26-273.

Pant, P., Harrison, R.M., 2013. Estimation of the contribution of road traffic emissions to particulate matter concentrations from field measurements: a review. Atmos. Environ. 77, 78-97.

Rexeis, M., Hausberger, S., 2009. Trend of vehicle emission levels until 2020-prognosis based on current vehicle measurements and future emission legislation. Atmos. Environ. 43 (31), 4689-4698.

Saito, T., 2004. The automotive application of discontinuously reinforced TiB-Ti composites. JOM 56 (5), 33-36.

Schauerte, O., 2003. Titanium in automotive production. Adv. Eng. Mater. 5 (6), 411-418.

Shi, G., Chen, Z., Bi, C., Wang, L., Teng, J., Li, Y., Xu, S., 2011. A comparative study of health risk of potentially toxic metals in urban and suburban road dust in the most populated city of China. Atmos. Environ. 45 (3), 764-771.

Suvarapu, L.N., Baek, S.-O., 2016. Determination of heavy metals in the ambient atmosphere a review. Toxicol. Ind. Health 0748233716654827.

Talebi, S., Abedi, M., 2005. Determination of arsenic in air particulates and diesel exhaust particulates by spectrophotometry. J. Environ. Sci. 17 (1), 156-158.

Thorpe, A., Harrison, R.M., 2008. Sources and properties of non-exhaust particulate matter from road traffic: a review. Sci. Total Environ. 400 (1), 270-282.

Timmers, V.R., Achten, P.A., 2016. Non-exhaust PM emissions from electric vehicles. Atmos. Environ. 134, 10-17.

Tomita, Y., Okabayashi, K., 1985. Mechanical properties of 0.40 pct C-Ni-Cr-Mo high strength steel having a mixed structure of martensite and bainite. Metall. Trans. A. 16 (1), 73-82.

Tomlinson, D.L., Wilson, J.G., Harris, C.R., Jeffrey, D.W., 1980. Problems in the assessment of heavy-metal levels in estuaries and the formation of a pollution index. Helgoländer Meeresun. 33 (1), 566-575.

URBIS, 2016. Urbis Model: Tool for Local Environmental Studies. http://www.tmleuven. be/methode/urbis/home.htm (Available at, last accessed on 2016).

USEPA, 1996. Soil Screening Guidance: Technical Background Document. Second Edition. EPA/540/R95/128. https://www.epa.gov/superfund/superfund-soilscreening-guidance (Available at, last accessed on 2016). 
USEPA, 2002. Supplemental Guidance for Developing Soil Screening Levels for Superfund Sites. OSWER 9355.4-24. https://www.epa.gov/superfund/superfund-soil-screeningguidance (Available at, last accessed on 2016).

Valotto, G., Varin, C., 2016. Characterization of hourly NOx atmospheric concentrations near the Venice International Airport with additive semi-parametric statistical models. Atmos. Res. 167, 216-223.

Valotto, G., Squizzato, S., Masiol, M., Zannoni, D., Visin, F., Rampazzo, G., 2014. Elemental characterization, sources and wind dependence of PM1 near Venice, Italy. Atmos. Res. 143, 371-379.

Valotto, G., Rampazzo, G., Visin, F., Gonella, F., Cattaruzza, E., Glisenti, A., Formenton, G., Tieppo, P., 2015. Environmental and traffic-related parameters affecting road dust composition: a multi-technique approach applied to Venice area (Italy). Atmos. Environ. 122, 596-608.

Valotto, G., Rampazzo, G., Gonella, F., Formenton, G., Ficotto, S., Giraldo, G., 2017a. Source apportionment of PAHs and n-alkanes bound to PM1 collected near the Venice highway. J. Environ. Sci. 54, 77-89.

Valotto, G., Cattaruzza, E., Bardelli, F., 2017b. Multi-edge X-ray absorption spectroscopy study of road dust samples from a traffic area of Venice using stoichiometric and environmental references. Spectrochim. Acta A Mol. Biomol. Spectrosc. 173 (2017), 971-978.

van der Denier Gon, H., Jozwicka, M., Cassee, F., Gerlofs-Nijland, M., 2012. The policy relevance of wear emissions from road transport, now and in the future. J. Air Waste Manage. Assoc. 13 (2), 136-149. (Report number: TNO-060-UT-2012-00732. Available at). http://repository.tudelft.nl/view/tno/uuid:18611a8c-20f3-4e8f-8495$11776 \mathrm{cde} 9 \mathrm{~cd} 2 /$.

Varrica, D., Bardelli, F., Dongarrà, G., Tamburo, E., 2013. Speciation of Sb in airborne particulate matter, vehicle brake linings, and brake pad wear residues. Atmos. Environ. 64, 18-24.

Vecchi, R., Marcazzan, G., Valli, G., 2007. A study on nighttime-daytime PM10 concentration and elemental composition in relation to atmospheric dispersion in the urban area of Milan (Italy). Atmos. Environ. 41 (10), 2136-2144.

Wan, D., Zhan, C., Yang, G., Liu, X., Yang, J., 2016. Preliminary assessment of health risks of potentially toxic elements in settled dust over Beijing urban area. Int. J. Environ. Res. Public Health 13 (5), 491.

Weinbruch, S., Worringen, A., Ebert, M., Scheuvens, D., Kandler, K., Pfeffer, U., Bruckmann, P., 2014. A quantitative estimation of the exhaust, abrasion and resuspension components of particulate traffic emissions using electron microscopy. Atmos. Environ. 99, 175-182.

Wik, A., Dave, G., 2009. Occurrence and effects of tire wear particles in the environment a critical review and an initial risk assessment. Environ. Pollut. 157 (1), 1-11.

Yekeen, T.A., Xu, X., Zhang, Y., Wu, Y., Kim, S., Reponen, T., Dietrich, K.N., Ho, S.-m., Chen, A., Huo, X., 2016. Assessment of health risk of trace metal pollution in surface soil and road dust from e-waste recycling area in China. Environ. Sci. Pollut. Res. $1-14$.

Yuan, H., Zhuang, G., Li, J., Wang, Z., Li, J., 2008. Mixing of mineral with pollution aerosols in dust season in Beijing: revealed by source apportionment study. Atmos. Environ. 42 (9), 2141-2157.

Zannoni, D., Valotto, G., Visin, F., Rampazzo, G., 2016. Sources and distribution of tracer elements in road dust: the Venice mainland case of study. J. Geochem. Explor. 166, 64-72.

Zhang, L., Chen, R., Lv, J., 2016. Spatial and seasonal variations of polycyclic aromatic hydrocarbons (PAHs) in ambient particulate matter (PM10, PM2.5) in three megacities in China and identification of major contributing source types. Bull. Environ. Contam. Toxicol. 96 (6), 827-832.

Zhao, H., Yin, C., Chen, M., Wang, W., Chris, J., Shan, B., 2009. Size distribution and diffuse pollution impacts of PAHs in street dust in urban streams in the Yangtze River Delta. J. Environ. Sci. 21 (2), 162-167. 